\title{
The Effects of Calcium Supplementation on Blood Lead Levels and Short-term Memory of Chronically Exposed Children: A Clinical Trial Study
}

\author{
Sri Sofyani ${ }^{1 *}$, Arlinda Sari Wahyuni ${ }^{2}$, Kusnandi Rusmil ${ }^{3}$, Aznan Lelo ${ }^{4}$ \\ ${ }^{1}$ Department of Child Health, Medical School, Haji Adam Malik Hospital, Universitas Sumatera Utara, Medan, Indonesia; \\ ${ }^{2}$ Department of Community Medicine, Medical School, Universitas Sumatera Utara, Medan, Indonesia; ${ }^{3}$ Department of Child \\ Health, Medical School, Hasan Sadikin Hospital, Universitas Padjadjaran, Bandung, Indonesia; ${ }^{4}$ Departement of Pharmacology \\ Medical School, Universitas Sumatera Utara, Medan, Indonesia
}

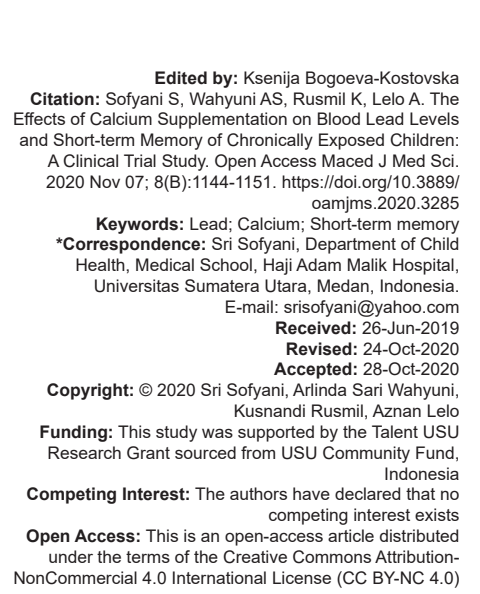

\section{Abstract}

AIM: The purpose of this study is to determine the effects of calcium supplementation to decrease blood lead levels (BLLs) of children at high risk for chronic lead poisoning and to determine its effects on short-term memory.

MATERIALS AND METHODS: Children aged 8-12 years lived in the highest traffic density in Medan randomly included in this quasi-experimental study, divided into two groups (control and supplementation group received table contain four hundred milligrams oral calcium twice daily for 3 months). Samples for BLLs were collected before and after 3 months of supplementation, and short-term memory measurements are carried out by picture and forward digital span test. Descriptive statistics were calculated at baseline and 3 months; comparison between before and after treatment was assessed with t-tests, $p<0.05$ considered statistically significant.

RESULTS: BLLs samples, who are exposed to lead for $>6$ months were ranging between $0.4-12 \mu \mathrm{g} / \mathrm{dL}$. Median BLLs in supplementation group before treatment was $2.1 \mu \mathrm{g} / \mathrm{dL}$ and after treatment was $0.01 \mu \mathrm{g} / \mathrm{dL}(p<0.01)$; difference between median in BLLs after treatment in supplementation group was $2.090 \mu \mathrm{g} / \mathrm{dL}(p=0.004)$. Score memory picture in the supplementation group before treatment was $61.4 \pm 24.83$ and after treatment was $76.21 \pm$ $15.97(p<0.01)$. Score memory digital span in the supplementation group before treatment was $5(3-7)$ and after treatment was $7(5-7)(p<0.01)$.

CONCLUSION: Three months of oral calcium supplementation $400 \mathrm{mg}$ twice daily for high-risk chronic lead poisoning children reduced BLLs significantly and improved their short-term memory.

\section{Introduction}

Lead is a naturally occurring metal, found throughout the environment. High levels of lead have entered the environment through human activities such as mining, industrial processes, and burning fuels [1]. Lead is used in hundreds of products, for example, as an additive in gasoline, in the production of batteries, as an additive in some paints, in solder, in making stained glass and crystal, for ammunition, in ceramic glazes, and in some cosmetics and traditional medicines. Drinking water delivered through lead pipes or pipes joined with lead solder may contain lead. Dust and soil are also a final resting place for the airborne lead from gasoline and dust from paint [2].

Children are most likely to be exposed to lead from automobile fumes and from ingestion of flakes and dust from decaying lead-based paint [3]. Lead in dust and soil can re-contaminate cleaned houses and contribute to elevated blood lead concentrations in children who play on bare, contaminated soil [4].
After it enters the body, lead is distributed to organs such as the kidneys, liver, and bones. The body stores lead in the teeth and bones, where it accumulates over time [5]. Lead poisoning is a serious child health [6]. This affects children's brain development and their measurable level of intelligence (IQ) [7], [8]. The highest risk children are the very young (including fetuses) because their central nervous systems are still developing and the impoverished [9]. Undernourished children are more susceptible to lead because their bodies absorb more lead if other nutrients, such as calcium, are lacking [10], [11], [12]. Even blood lead levels (BLLs) that are around $10 \mathrm{ug} / \mathrm{dl}$, once thought to be a safe level, may lead to decreased IQ in children, behavioral difficulties, and learning problems [13], [14], [15], [16], [17]

In Indonesia, children who live in urban areas with higher traffic density have a higher risk of lead poisoning [18], [19]. Our data indicate that Indonesian children living in an urban area are at increased risk for BLLs above the actual acceptable limit [20]. The increasing number of industries in Indonesia has been associated with rising heavy metal pollution in several 
areas such as in Jakarta and Medan [21], [22], [23], [24]. Research conducted in the city of Medan and Yogyakarta found that there is an apparent link between the increases of the intensity of a motor vehicle with the air lead levels in these two cities [25]. In Medan, air lead levels are highest at terminal Amplas, that is, $32.67 \mathrm{ug} / \mathrm{m}^{3}$, then at Pinang Baris and at Jalan Brigjend Katamso at the time of observation from 13.00 to 14.00 is $23 \mathrm{ug} / \mathrm{m}^{3}$ [26]. While the air lead level threshold based on Government Regulation on air pollution control is $2 \mathrm{ug} / \mathrm{m}^{3}$, this indicates that the air lead levels far above the city of Medan threshold value [27].

The definition of an elevated concentration of lead in the blood, according to the Centers for Disease Control and Prevention (CDC 1991), is $10 \mathrm{ug} / \mathrm{dl}$ [28]. However, evidence indicating that some health effects can occur below this threshold is accumulating [29], [30]. Recent analyses suggest that health effects may become apparent at concentrations of $<5 \mu \mathrm{g} / \mathrm{dl}$ and, indeed, that no evidence exists for a threshold, even at $1 \mu \mathrm{g} / \mathrm{dl}$ [31]. For the purpose of this study, the concentration of blood-lead incurring the lowest population risk was considered to be $0-1 \mu \mathrm{g} / \mathrm{dl}$, in the absence of scientific consensus and pending further investigation. The measurement of blood-lead concentration in pre-industrial humans has shown that the contribution of natural sources of lead to human exposure is small; Flegal and Smith have estimated that pre-industrial humans had blood-lead concentrations of only $0.016 \mu \mathrm{g} / \mathrm{dl}$ [32].

From several previous studies, it is known that the administration of calcium in some cases can reduce BLLs [33], [34].

Given the health problems posed by lead in children quite dangerous as described by previous researchers, it is considered very necessary to find a way to prevent the effects of chronic lead exposure in children. Given the lead continuously removed by the exhaust of motor vehicles, leaded gasoline usage and industrial pollution [35] and also leaded paint in the city of Medan [36]; it can be absorbed by the body through the skin and breathing, plus the nature of the accumulation of lead that has been absorbed in the body, it is necessary to obtain a way to prevent elevated levels of lead or to drop lead levels in the blood.

The treatment options for children with BLL $<45 \mu \mathrm{g} / \mathrm{dL}$ are limited because chelation therapy is generally not indicated, but Calcium (Ca) and lead $(\mathrm{Pb})$ interactions are well documented [37]. Studies have shown that calcium is one ingredient that can lower BLLs of children [33], [38], [39], [40], but the results were different, some did not find any benefit, some did; therefore, the role of calcium at reducing BLLs needs to be investigated.

The purpose of this study was to determine the effect of calcium supplementation on short-term memory of elementary school children who go to school in areas exposed to lead over a long period of time and determine whether BLLs affect a child's short-term memory.

\section{Research Methodology}

\section{Study design and population}

This quasi-experimental design of a randomized clinical trial was conducted in school children (aged 8-12 years old, at the stage of concrete operational based on Piaget's Cognitive Theory). The study subjects were at high risk of lead pollution in the city of Medan, who is domiciled and doing activities (school) in overcrowded vehicles. The exclusion criteria were children with kidney failure, abnormalities of brain dysfunction, history of allergies, or resigned after being given an explanation.

\section{Measures}

Subjects were divided into two groups using simple random sampling; one group as control ( $n=25)$ and another group $(n=35)$ were treated by giving calcium supplements at a dose of $2 \times 400$ mg daily for 3 months. Venous blood was collected from each child using vacutainer as much as $\pm 6 \mathrm{cc}$, before and after 3 months of treatment. The content of lead in blood $(\mathrm{mg} / \mathrm{dL})$ was measured in duplicate samples by atomic absorption spectrophotometry using a PerkinElmer spectrophotometer. A coefficient of variation $<5 \%$ was reached before the analysis of actual samples. Digit Span Memory Test Online was used to assess short time memory. Study staff measured children anthropometry and administered feeding and demographic questionnaires before treatment was started. Children's weight was measured in light clothing using a Seca scale. Height was measured using a Seca Stable Stadiometer for mobile height measurement.

\section{Sampling process}

Blood sampling to assess BLLs was carried out during school hours after approved by the Principal. A prior meeting had been held with students' parents who attended school in grades 4, 5, and 6 aged 8-12 years old. Parents and children who met the inclusion and exclusion criteria were explained about the research that would be conducted and requested approval. Parents and children are also asked to fill in the prepared questionnaire.

Staff from the Pramita Clinical Laboratory, Medan, who came to the school, carried out blood sampling. The National Medical Laboratory Accreditation Committee, accredited by ISO 15189: 
2012, has accredited this Pramita Clinical Laboratory. Laboratory staff came to school to collect student venous blood samples.

There were 62 children who fulfill the inclusion and exclusion criteria and were willing to take part in this study, but only 60 people get permission from their parents. Randomization was done to allocate the respondents into the supplementation and the control group. Among these 60 children who took the Digit Span Memory Task Online test for short-term memory examinations and then the blood samples were taken before and after the intervention, 57 children were remains (three children were dropped due to fear when taking blood samples). Hence, a total of 57 children were included in this study, which was divided into 35 in the intervention group and 22 in the control group.

Every morning before starting the lesson, subjects chewed/swallowed the supplement caplet. At home, children chewed their supplements every day at dinner time after sunset in front of their parents. On school holidays, their parents give the morning and evening supplements. Likewise, if the child was not present at school because of illness or for other reasons, supplementation is done at home in the presence of his parents. The distribution of supplements was done at school 3 times (once a month) in a meeting between the authors, homerooms, and parents. At the meeting, a discussion was held on the implementation of given supplementation.

Examination of lead levels in the blood and a second memory test was carried out after 3 months (90 days) of supplementation.

\section{Statistical analysis}

Descriptive statistics were calculated for the total sample at two visits (baseline, and 3 months). Means, standard deviations, and medians and ranges were used to summarize continuous variables and proportions for categorical variables. The comparison between two treatments was assessed by Student's t-tests. Ordinal data when the assumptions of the t-test are not meet were assessed by Mann-Whitney $U$ test. Statistical significance was defined as $p<$ 0.05 .

\section{Ethics}

The study was conducted in Private Elementary Schools Al-Wasliyah Timbang Deli, Jalan Pertahanan, District Medan Amplas, Medan, Province of Sumatera Utara. Assent was obtained from the participated subjects with consent from their parents/guardians. The study was conducted after obtaining approval from the Health Research Ethical Committee of Medical School, Universitas Sumatera Utara.

\section{Results}

\section{Study population}

The result showed that the percentage of the respondent's gender was $56 \%$ for male and $44 \%$ for female. More than half of the participants were wellnourished and with family income below the minimum wages (Table 1).

\section{Overall feeding patterns}

The overall dietary patterns of respondents in both groups were almost the same. Not all respondents in their daily lives eat nutritious food in accordance with balanced food guidelines. There were $29.2 \%$ of respondents who did not consume milk; eggs and vegetable protein are the most consumed sources of protein. Most of the respondents were snacking on the roadside, that is, on street vendors who were around the school with their wheelbarrows. There is no canteen in the school. The habit of handwashing with soap was carried out by $77.9 \%$ of respondents. Respondents also carried out bad habits such as biting nails, pencils, or eating objects other than food.

Headaches were one of the symptoms that annoy respondents when studying at school and at home, although not all respondents often experience them (headaches were experienced by $29.82 \%$ of respondents) (Tables 2 and 3).

Table 1: Characteristics of the subjects

\begin{tabular}{|c|c|c|}
\hline Characteristics & $\begin{array}{l}\text { Supplementation groups no } \\
(\mathrm{n}=35)\end{array}$ & $\begin{array}{l}\text { Control group } \\
(n=22)\end{array}$ \\
\hline \multicolumn{3}{|l|}{ Age (years) } \\
\hline Range & $8-12$ & $8-12$ \\
\hline Mean & 10.09 & 9.82 \\
\hline Median & 10 & 9.5 \\
\hline \multicolumn{3}{|l|}{ Gender, n (\%) } \\
\hline Male & $18(51.43)$ & $14(63.64)$ \\
\hline Female & $17(48.57)$ & $8(36.36)$ \\
\hline \multicolumn{3}{|l|}{ Child's weight (kg) } \\
\hline Interval & $21-52$ & $18-46$ \\
\hline Mean & 30.35 & 27.06 \\
\hline Median & 29 & 26 \\
\hline \multicolumn{3}{|l|}{ Child's height $(\mathrm{cm})$} \\
\hline Interval & $120-147$ & $119.5-146$ \\
\hline Mean & 131.60 & 128.97 \\
\hline Median & 131 & 127 \\
\hline \multicolumn{3}{|l|}{ BMI } \\
\hline Range & $11.7-25.8$ & $11.8-25.05$ \\
\hline Mean & 17.35 & 15.97 \\
\hline Median & 16.32 & 14.94 \\
\hline \multicolumn{3}{|l|}{ Nutrition status, n (\%) } \\
\hline Malnutrition & $1(2.86)$ & $2(9.09)$ \\
\hline Under nutrition & $2(5.71)$ & $6(27.27)$ \\
\hline Well-nourished & $21(60)$ & $11(50)$ \\
\hline Overweight & $7(20)$ & $2(9.09)$ \\
\hline Obese & $4(11.43)$ & $1(4.55)$ \\
\hline \multicolumn{3}{|l|}{ Income, n (\%) } \\
\hline Below the minimum wages & $18(51.43)$ & $12(54.55)$ \\
\hline Above the minimum wages & $17(48.57)$ & $10(45.45)$ \\
\hline
\end{tabular}

\section{Short-term memory scores}

After all the blood samples were taken, in the following week, the short-term memory test was started. Short-term memory testing was done 
Table 2: Dietary patterns and behavior of the subjects

\begin{tabular}{|c|c|c|}
\hline Characteristics & Supplementation group $(\mathrm{n}=35)$ & Control group $(n=22)$ \\
\hline \multicolumn{3}{|l|}{ Drink milk n (\%) } \\
\hline Yes & $25(71.43)$ & $15(68.18)$ \\
\hline No & $10(28.57)$ & $7(31.82)$ \\
\hline \multicolumn{3}{|c|}{ Frequently eat vegetable $\mathrm{n}(\%)$} \\
\hline Yes & $32(91.43)$ & $18(81.82)$ \\
\hline No & $3(8.57)$ & $4(18.18)$ \\
\hline \multicolumn{3}{|l|}{ Frequently eat tofu, $\mathrm{n}(\%)$} \\
\hline Yes & $22(62.86)$ & $14(63.64)$ \\
\hline No & $13(37.14)$ & $8(36.36)$ \\
\hline \multicolumn{3}{|l|}{ Frequently eat eggs, $n(\%)$} \\
\hline Yes & $30(85.70)$ & $18(81.8)$ \\
\hline No & $5(14.30)$ & $4(18.2)$ \\
\hline \multicolumn{3}{|l|}{ Roadside snacks, $n(\%)$} \\
\hline Yes & $30(85.71)$ & $21(95.45)$ \\
\hline No & $5(14.29)$ & $1(4.55)$ \\
\hline \multicolumn{3}{|l|}{ Hand washing, $\mathrm{n}(\%)$} \\
\hline Yes & $28(80.00)$ & $16(72.73)$ \\
\hline No & $6(17.14)$ & $4(18.18)$ \\
\hline $\begin{array}{l}\text { Hand washing without } \\
\text { soap }\end{array}$ & $1(2.86)$ & $2(9.09)$ \\
\hline \multicolumn{3}{|c|}{ Eat other objects than food, $\mathrm{n}(\%)$} \\
\hline Yes & $13(37.14)$ & $13(59.09)$ \\
\hline No & $22(62.86)$ & $9(40.09)$ \\
\hline \multicolumn{3}{|l|}{ Eat canned food, $\mathrm{n}(\%)$} \\
\hline Yes & $18(51.43)$ & $11(50)$ \\
\hline No & $17(48.57)$ & $11(50)$ \\
\hline \multicolumn{3}{|l|}{ Nail biting, $\mathrm{n}(\%)$} \\
\hline Yes & $2(5.71)$ & $9(40.91)$ \\
\hline No & $33(94.29)$ & $13(59.09)$ \\
\hline \multicolumn{3}{|l|}{ Frequent headaches, $\mathrm{n}(\%)$} \\
\hline Yes & $14(40)$ & $3(13.64)$ \\
\hline No & $21(60)$ & $19(86.36)$ \\
\hline
\end{tabular}

using a digit span memory test online (https://www. memorylosstess.com/free-working-memory-testonline/) (respondents are asked to retype forward sequences of numbers that appear on the laptop screen, the span used is slow (slow) and short-term memory test) (https://www.memorylosstest.com/ free-short-term-memory-test-online/?pton).

Table 3: House' of the subjects

\begin{tabular}{lll}
\hline Characteristics & $\begin{array}{l}\text { Supplementation } \\
\text { group }(\mathrm{n}=35)\end{array}$ & $\begin{array}{l}\text { Control group } \\
(\mathrm{n}=22)\end{array}$ \\
\hline $\begin{array}{l}\text { Residence, } \mathrm{n}(\%) \\
\quad \text { Great roadside } \\
\quad \begin{array}{l}\text { The highway that is not } \\
\text { crowded }\end{array}\end{array}$ & $9(25.7)$ & $3(13.6)$ \\
$\quad$ & $8(22.8)$ & $15(68.2)$ \\
$\quad \begin{array}{l}\text { The road is not crowded road } \\
\text { Water source, } \mathrm{n}(\%)\end{array}$ & $18(51.4)$ & $4(18.2)$ \\
$\quad$ Well water & $4(11.4)$ & $3(13.6)$ \\
$\quad \begin{array}{l}\text { Tap water } \\
\text { Bottled water }\end{array}$ & $15(42.9)$ & $15(68.2)$ \\
$\begin{array}{l}\text { A painted house, } \mathrm{n}(\%) \\
\text { Yes }\end{array}$ & $16(45.7)$ & $4(18.2)$ \\
$\quad \begin{array}{l}\text { No } \\
\text { Painted part, } \mathrm{n}(\%)\end{array}$ & $33(94.3)$ & $21(95.5)$ \\
$\quad$ Inside and outside & $2(5.7)$ & $1(4.5)$ \\
\hline
\end{tabular}

A series of images will appear on the laptop screen during the test. When an image appears repeatedly, the respondent was asked to press the space bar on the laptop keyboard.

The performance was defined as good if obtained $90 \%+$ accuracy. Good response time in choosing the right image is $<900 \mathrm{~ms}(0.9 \mathrm{~s})$.

In the initial examination, the picture memory values score was 64 (4-100) (median [min-max]) while the memory picture response time value was $1519.61 \pm$ 287.96 (mean \pm SD). Digital span memory values were 5 (3-7) (median [min-max]) (Table 4).

Table 4: Short-term memory scores and initial blood lead levels

\begin{tabular}{ll}
\hline Variables & Scores \\
\hline Memory picture $(\%)^{*}$ & $64(4-100)$ \\
Memory picture $(\text { second })^{\star *}$ & $1519.61 \pm 287.96$ \\
Memory digital span ${ }^{*}$ & $5(3-7)$ \\
Blood lead level ${ }^{*} \mathrm{\mu g} / \mathrm{dL}$ & $2.106(0.4-12)$ \\
\hline${ }^{*}$ Data are abnormally distributed by median (min-max). ${ }^{* *}$ Data are normally distributed by mean \pm SD.
\end{tabular}

At the initial examination, there were four children who performed well for accuracy in remembering the images that appeared on the laptop screen, but none of them received response times below $0.9 \mathrm{~s}$.

Table 5: Blood lead levels, memory picture, and digital span memory based on gender

\begin{tabular}{llll}
\hline Variables & Male $(\mathrm{n}=32)$ & Female $(\mathrm{n}=25)$ & $\mathrm{p}$ \\
\hline Blood lead levels & $2.104(0.4-10)$ & $2.015(0.4-12)$ & $0.872^{*}$ \\
Memory picture $(\%)$ & $63.84 \pm 18.55$ & $52.52 \pm 26.31$ & $0.1^{* *}$ \\
Memory digital span & $5(5-7)$ & $5(3-7)$ & $0.047^{*}$ \\
\hline${ }^{*}$ Mann-Whitney u test. ${ }^{*}$ Unpaired t-test. & &
\end{tabular}

The memory picture score of the group that received supplementation before supplementation was $61.4 \pm 24.83$, while in the control group, it was $55.7 \pm$ 22.58. There were no statistically significant differences between the score of the two groups' memory picture before supplementation ( $p=0.292$ ). (Tables 5 and 6)

Table 6: Memory picture scores before and after supplementation

\begin{tabular}{llll}
\hline Variables & \multicolumn{2}{l}{ Memory picture score } & $\mathrm{p}$ \\
\cline { 2 - 3 } & Before & After & \\
\hline Supplementation group & 0.41 \\
Control group $^{\star *}$ & $61.4 \pm 24.83$ & $76.21 \pm 15.97<0.01$ & \\
\hline${ }^{* *}$ Data are abnormally distributed. & $55.7 \pm 22.58$ & $55.91 \pm 22.58$ &
\end{tabular}

There was an increase in memory picture scores that were statistically significant in the group that received calcium supplementation $(p<0.01)$.

There was a statistically significant increase in the memory digital span score in the intervention group after receiving supplementation for 3 months $(p<0.01)$ (Table 7).

Table 7: Digital span memory scores before and after supplementation

\begin{tabular}{llll}
\hline Variables & \multicolumn{2}{l}{ Memory digital span } & $\mathrm{p}$ \\
\cline { 2 - 3 } & Before supplementation & After supplementation & \\
\hline Supplementation group & $5(3-7)$ & $7(5-7)$ & $<0.01$ \\
Control group* & $6(4-7)$ & $6(4-7)$ & 0.057 \\
\hline${ }^{*}$ Data are not normally distributed. & &
\end{tabular}

\section{$B L L s$}

BLLs of the participant were ranging between 0.4 and $12 \mu \mathrm{g} / \mathrm{dL}$ with a median of $2.106 \mu \mathrm{g} / \mathrm{dL}$. Samples with BLLs above $10 \mu \mathrm{g} / \mathrm{dL}$ are girls. There was no significant difference between the BLLs of boys and girls.

BLLs before supplementation in the supplemented group, min-max was 2.1-9 $\mu \mathrm{g} /$ $\mathrm{dL}$ with a median of $2.1 \mu \mathrm{g} / \mathrm{dL}$. While BLLs before supplementation in the control group min-max were $0.4-12 \mu \mathrm{g} / \mathrm{dL}$. There were no significant differences in the BLLs of the control group and intervention group before the intervention ( $p=0.582$ ). After 3 months of calcium supplementation, a decrease in BLLs in the group receiving calcium supplementation was found statistically significant $(p<0.01)$ (Table 8).

Table 8: Blood lead levels before and after supplementation

\begin{tabular}{llll}
\hline Variables & \multicolumn{2}{l}{ Blood lead level $(\mu \mathrm{g} / \mathrm{dL})$} & $\mathrm{p}$ \\
\cline { 2 - 3 } & Before & After & \\
\hline Supplementation group & $2.1(2.1-9)$ & 0.01 & $<0.01$ \\
Control group* & $2.04(0.4-12)$ & $2.02(0.41-12.1)$ & 0.231 \\
\hline "Data are abnormally distributed. & & \\
\hline
\end{tabular}


Statistically, a significant relationship was found between the changes in sample BLLs and memory picture scores (moderate correlation) and digital span memory (weak correlation) and digital span memory (weak correlation). However, the changes in BLLs were found not significantly related to memory picture (time) (Table 9).

Table 9: Correlation of the changes of the blood lead levels with short-term memory scores

\begin{tabular}{lll}
\hline Variables & \multicolumn{2}{l}{ Changes in blood lead levels } \\
\cline { 2 - 3 } & $\mathrm{R}$ & $\mathrm{p}$ \\
\hline Memory picture & -0.516 & 0.000 \\
Memory picture (second) & 0.251 & 0.06 \\
Memory digital span & -0.386 & 0.003 \\
\hline
\end{tabular}

\section{Discussion}

Lead can affect the brain in various areas, including the cerebral cortex, cerebellum, and hippocampus [7], [41], [42]. In this research, increase short-term memory function is found when the lead levels in blood decrease after 3 months of calcium supplementation. Since short-term memory score is a vital component of one's IQ score; therefore, the increase of short-term memory will enhance the IQ score [43], [44], [45], [46]. The results of this study are in accordance with the prior findings, in which exposure to lead can reduce children's $I Q$ and impaired their learning ability.

Evidence showed that dietary calcium decreases gastrointestinal lead absorption and thereby will reduce lead toxicity [11], [47]. A large amount of experimental data supports the hypothesis of calcium supplementation potential roles in lead poisoning treatment. Ca-binding proteins have a high affinity for $\mathrm{Pb}$ [48]. Studies showed that increasing BLL is found in rodents with calcium-deficient diet compare with those with calcium-sufficient diet [49]. Studies using an isotope of Stable $\mathrm{Pb}$ in adults with $\mathrm{Ca}$ supplementation showed a decrease of $\mathrm{Pb}$ absorption [50], [51], [52], [53]. Some studies showed that there is a correlation of increasing dietary $\mathrm{Ca}$ with the decrease of gastrointestinal lead absorption and BLL, while some studies showed no correlation [4], [12], [50], [54]. Lanphear et al. found a correlation between BLL and Ca intake in a cohort study of 12- to 24-month old children with $900 \mathrm{mg} \mathrm{Ca}$ per day.

A 9-month experimental study showed that there is no benefit toward baby of $\mathrm{Pb}$ poisoning, given $\mathrm{Ca}$ glycerophosphate supplement $(188 \mathrm{mg} / \mathrm{L}$ vs. $465 \mathrm{mg} / \mathrm{L})$ as the treatment of it. BLL increased $2.4 \mu \mathrm{g} / \mathrm{dL}$ in the un-supplemented and $2 \mu \mathrm{g} / \mathrm{dL}$ in the supplemented group. Interestingly, there was no effect of supplementation on urinary $\mathrm{Ca}$ excretion or iron status [33].

The published data of the potential role of $\mathrm{Ca}$ supplementation in the treatment of mild to moderate children lead poisoning are limited. A single uncontrolled study examined the potential effects of Ca-supplementation on a Ca-deficient and leadpoisoned population in China. The source of lead exposure in this group was from leaded gasoline usage and industrial pollution. Shen et al. provided a total daily intake of $800 \mathrm{mg} \mathrm{Ca}$ (the recommended dietary daily allowance for this age group) to 35 of 49- to 70-monthold children and to those having $300 \mathrm{mg} / \mathrm{day}$ of pretreatment $\mathrm{Ca}$ intake. The decrease of $10 \mu \mathrm{g} / \mathrm{dL}$ in BLL was observed in 2 months, although lead exposure was presumably ongoing and changed [55].

In our study using 800 mg/day calcium supplementation, we found the difference of $2.09 \mu \mathrm{g} / \mathrm{dL}$ between the median of BLLs before and after 3 months of follow-up in a Ca supplemented children, $p<0.01$, significantly different (min 2.09 and $\max 8.99 \mu \mathrm{g} / \mathrm{dL}$ ). Therefore, we conclude that a total of $800 \mathrm{mg}$ supplementation will not cause toxicity. Although there will be adverse events caused by it, such as myocard infarct, constipation, colorectal neoplasms, and kidney stone [56]. Shortterm memory score, along with decreasing levels of lead in blood, is found to increase and according to statistical calculations, the increase is meaningful. From this study, it can be seen that if BLLs have not or are not at a toxic level, short-term memory scores can be better if BLLs are lowered by giving calcium supplements. This situation can occur in children whose daily calcium intake is low, as experienced by respondents in this study.

Physiologically calcium level is determined by the levels of Vitamin $D$ in the blood [57]. The relationship of serum Vitamin $D$ and whole-blood lead is possibly influenced by growth and/or calcium homeostasis in some children and adults. Low dietary intake of Vitamin D and calcium are known risk factors for high bone lead levels. Optimal Vitamin D status is known to have beneficial health effects and Vitamin D supplements are commonly used. It has been suggested that Vitamin $D$ supplementation may increase blood lead in children and adults with previous lead exposure. In fact, high-dose Vitamin D3 supplementation and the concomitant increased serum 25D did not result in increased whole-blood lead concentration [58].

Socioeconomic status has also received attention, is there any effect on lead exposure in children [59], [60]. The Third National Health and Nutrition Examination Survey (NHANES III) from 1991 to 1998 examined the BLLs of American children [12]. The results showed that $21 \%$ of children residing in the city compared to $5.8 \%$ of children on the outskirts of the city had BLLs that were equal to or more than the maximum allowed by the CDC which was $10 \mu \mathrm{g} /$ $\mathrm{dL}$. When paying attention to the child's family income, it turned out that $16.3 \%$ of children with a low family income had BLLs of $\mathrm{g} 10 \mu \mathrm{g} / \mathrm{dL}$, while in middle-income 
families, there were $5.4 \%$ and only $4.0 \%$ of families with high income [50]. In this study, more than half of participants came from families with income below the UMR (i.e., $51.4 \%$ in the supplemented group and $54.5 \%$ in the control group) and children with BLLs above the median value were from low-income families.

Some of the things that could be a weakness in this study were, the researchers did not measure the calcium levels and blood Vitamin D levels of the respondents before and after administration of calcium, the adequacy of respondents' calcium intake was only seen from interviewing daily intake using a questionnaire alone and not calculating more precisely how much calcium intake is consumed by respondents daily. This study also does not use large population samples so that BLLs cannot be grouped in a particular grouping and no respondents have toxic lead levels so that they cannot see more clearly how many lead levels can go down with calcium.

\section{Conclusion}

We demonstrated that the blood leads levels of Al Washliyah Elementary School children who are exposed to lead for a long time (school and their home are located in areas with high levels of air lead) ranging from 0.4 to $12 \mathrm{~g} / \mathrm{dL}$, with a median of $2101 \mathrm{~g} /$ $\mathrm{dL}$. Providing calcium $2 \times 400 \mathrm{mg}$ supplements for 3 months can reduce the BLLs of the Al Washliyah Elementary School children, who are 8-12 years of age, have BLL between 0.4 and $12 \mu \mathrm{g} / \mathrm{dL}$. After 3 months of calcium supplementation, we found a decrease in BLLs in the supplemented group, which was statistically significant $(p<0.01)$. The median decrease in BLLs in the supplementation group was $2.09 \mu \mathrm{g} / \mathrm{dl}$ (min the decrease was $2.09 \mu \mathrm{g} / \mathrm{dL}$ and the maximum decrease was $8.99 \mu \mathrm{g} / \mathrm{dL})$.

Our finding of the providing calcium $2 \times 400 \mathrm{mg}$ supplements for 3 months can improve the short-term memory of elementary school children exposed to lead for a long time and the BLLs affect a child's short-term memory.

Prevention must be carried out in preventing brain development and behavioral disorders related to exposure to lead; by reducing BLLs in each individual to the most minimal point is very necessary. For children exposed to lead, intake of calcium has to be sufficient as the recommended amount according to his/her age. For children who are at risk, it is also recommended to check the short-term memory and examine their BLLs is carried out on all children who are chronically exposed to lead.

\section{Acknowledgments}

We thank the school principal, Mr. Rozali, all of the teachers at Al Washliyah Timbang Deli Private Elementary School, our residents, and co-assistant study staff at Haji Adam Malik Hospital for their support of this study. We thank the families and children who participated in this study.

\section{References}

1. Papanikolaou NC, Hatzidaki EG, Belivanis S, Tzanakakis GN Tsatsakis AM. Lead toxicity update. A brief review. Med Sci Monit. 2005;11(10):RA329-36.

PMid:16192916

2. World Health Organization. Childhood Lead Poisoning. WHP Press; 2010.

3. Committee on Measuring Lead in Critical Population. Measuring Lead Exposure in Infant, Children and other Sensitive Populations. Washington, DC: United States National Academy Press; 1993. https://doi.org/10.17226/2232

4. Lanphear BP, Hornung R, Ho M, Howard CR, Eberly S, Knauf K. Environmental lead exposure during early childhood. J Pediatr. 2002;140(1):40-7. https://doi.org/10.1067/mpd.2002.120513 PMid:11815762

5. Sauk JJ, Somerman MJ. Physiology of bone: Mineral compartment proteins as candidates for environmental perturbation by lead. Environ Health Perspect. 1991;91:9-16. https://doi.org/10.1289/ehp.91919 PMid:2040255

6. Audesirk, G. Effects of lead exposure on the physiology of neurons. Prog Neurobiol. 1985;24(3):199-231.

7. Bughurst PA, McMchael AJ, Wigg NR, Vimpani GV, Robertson EF, Roberts RJ, et al. Environmental exposure to lead and children's intelligence at the age of seven years. The port pirie cohort study. N Engl J Med. 1992;327(18):1279-84. https://doi.org/10.1056/nejm199210293271805

PMid:1383818

8. Hornung RW, Lanphear BP, Dietrich KN. Age of greatest susceptibility to childhood lead exposure: A new statistical approach. Environ Health Perspect. 2009;117(8):1309-12. https://doi.org/10.1289/ehp.0800426

PMid:19672413

9. Bijoor AR, Sudha S, Venkatesh T. Neurochemical and neurobehavioral effects of low lead exposure on the developing brain. Ind J Clin Biochem. 2012;27(2):147-51. https://doi. org/10.1007/s12291-012-0190-2

PMid:23543765

10. Mahaffey KR. Nutritional factors and susceptibility to lead toxicity. Environ Health Perspect. 1974;7:107. PMid:4831135

11. Ahamed M, Siddiqui MK. Environmental lead toxicity and nutritional factors. Clin Nutr. 2007;26(4):400-8. PMid:17499891

12. Mahaffey KR, Gartside PS, Glueck CJ. Blood lead levels and dietary calcium intake in 1-to 11-year-old children: The second national health and nutrition examination survey. Pediatrics. 
1986;78(2):257-62.

PMid:3488536

13. Roy A, Bellinger $\mathrm{D}$, Hu H, Schwart J, Ettinger AS, Wright RO et al. Lead exposure and behavior among children in Chennai, India. Environ Health Perspect. 2009;117(10):1607-11. https:// doi.org/10.1289/ehp.0900625

PMid:20019913

14. Grandjean P. Even low-dose lead exposure is hazardous. Lancet. 2010;376(9744):855-6. https://doi.org/10.1016/ s0140-6736(10)60745-3

PMid:20833288

15. Bellinger DC. A strategy for comparing the contributions of environmental chemicals and other risk factors to neurodevelopment of children. Environ Health Perspect. 2012;120(4):501-7. https://doi.org/10.1289/ehp.1104170 PMid:22182676

16. Grandjean P, Landrigan PJ. Neurobehavioral effects of developmental toxicity. Lancet Neurol. 2014;13(3):330-8. PMid:24556010

17. Lubis NM, Sofyani S, Lubis B. Association between blood lead levels with behavior disorders in elementary school age children. Paediatr Indones. 2016;56(Supp):11.

18. Albalak R, Noonan G, Buchana S, Flanders WD, Crawford CG Kim D, et al. Blood lead levels and risk factors for lead poisoning among children in Jakarta, Indonesia. Science Total Environ. 2003;301(1-3):75-85. https://doi.org/10.1016/ s0048-9697(02)00297-8

PMid: 12493187

19. Gusnita, D. Pencemaran logam berat timbal $(\mathrm{Pb})$ di udara dan upaya penghapusan bensin bertimbal. Ber Dirgantara. 2012;13(3)

20. Heinze. Assessment of Lead Exposure in School Children from Jakarta; 1998. Available from: http://www.ehp.niehs, nih. gov.members/1998/106p499-501heinze/heize-full.html. [Last accessed on $2020 \mathrm{Feb}$ 10].

21. Amin B. Akumulasi dan Distribusi Logam Berat $\mathrm{Pb}$ dan $\mathrm{Cu}$ Pada Mangrove (Avicennia marina) di Perairan Pantai Dumai, Riau [Translation: Accumulation and Distribution of Heavy Metal Pb dan $\mathrm{Cu}$ on Mangrove (Avicenna marina) in Coastal Dumai, Riau] IN INDONESIAN] University of Riau Indonesia; 2001. https://doi.org/10.13170/depik.7.3.11020

22. Anggarini D. Analysis of heavy Metal $\mathrm{Pb}, \mathrm{Cd}, \mathrm{Cu}$ and $\mathrm{Zn}$ in a Seawater Sedimen and Gelainacoaxans in Coastal Dumai, Riau; 2007. Available from: http://www.images.cientherell4. multiply.multiplycontent.com.journal/item/1. [Last accessed on 2020 Feb 10].

23. Edward L. Dampak pencemaran logam berat terhadap kualitas air laut dan sumber daya perikanan (Studi kasus kematian massal ikan-ikan di Teluk. Makara Sains. 2004;8(2):52-8. https://doi.org/10.7454/mss.v8i2.414

24. Hasan W. Pencegahan Keracunan Timbal Kronis Pada Pekerja Dewasa Dengan Suplemen Kalsium. Vol. 16. Makara, Kesehatan; 2012.

25. Suyitno M, Vistha FM, Khasanah F, Murtinah S. Absorpsi Timbal $(\mathrm{Pb})$ Dalam gas Buang Kendaraan Bermotor Bensin Dengan Karbon Aktif. Yogyakarta: Universitas Negeri Yogyakarta; 2006.

26. Sitohang R. Pengaruh Intensitas Kendaraan Bermotor Terhadap Emisi Logam Timbal ke Dalam Udara Ambien di Kota Medan [Thesis] Indonesia. Utara: Universitas Sumatera Utara; 2001.

27. Girsang, E. Hubungan Kadar Timbal di Udara Ambien Dengan Timbal Dalam Darah pada Pegawai Dinas Perhubungan Terminal Antar Kota Medan (Master's Thesis). Utara: Postgraduate thesis Universitas Sumatera Utara; 2008. p. 36-52. https://doi.org/10.14238/sp8.3.2006.238-43

28. Needleman H. Lead poisoning. Annu Rev Med. 2004;55:209-22.
PMid: 14746518

29. Nawrot TS, Staessen J. A Low-level environmental exposure to lead unmasked as a silent killer. Circulation. 2006;114(13):13479. https://doi.org/10.1161/circulationaha.106.650440 PMid:17000919

30. Nevin, R. Understanding international crime trends: The legacy of preschool lead exposure. Environ Res. 2007;104(3):315-36. https://doi.org/10.1016/j.envres.2007.02.008

PMid: 17451672

31. World Health Organization. Brief Guide to Analytical Methods for Measuring Lead in Blood. Geneva: World Health Organization; 2011.

32. Flegal A, Smith DR. Lead levels in preindustrial human. $N$ Eng J Med. 1992;326(19):1293-4.

PMid:1560812

33. Sargent JD, Dalton MA, O'Connor GT, Olmstead EM, Klein RZ Randomized trial of calcium glycerophosphate-supplemented infant formula to prevent lead absorption. Am J Clin Nutr. 1999;69(6):1224-30. https://doi.org/10.1093/ajcn/69.6.1224

34. Fullmer CS. Intestinal calcium and lead absorption: Effect of dietary lead and calcium. Environ Res. 1991:54(2):159-69. https://doi.org/10.1016/s0013-9351(05)80098-2 PMid:2029877

35. Suherni. Lead Poisoning in Indonesia. The LEAD Group Inc.; 2010. p. 1-16.

36. Santi DN. Pencemaran Udara Oleh Timbal $(\mathrm{Pb})$ Serta Penanggulangannya. Utara: Fakultas Kedokteran Universitas Sumatera Utara; 2001

37. Keller B, Faciano A, Tsega A, Ehrlich J. Epidemiologic characteristics of children with blood lead levels $\geq 45 \mu \mathrm{g} / \mathrm{dL}$. J Pediatr. 2017;180:229-34. https://doi. org/10.1016/j.jpeds.2016.09.017 PMid:27771006

38. Markowitz ME, Sinnet M, Rosen JF. Randomized trial of calcium supplementation for childhood lead poisoning. Pediatrics. 2004;113(1 Pt 1):e34-9. https://doi.org/10.1542/peds.113.1.e34 PMid:14702492

39. Haryanto B. Pengaruh Suplemen Kalsium Terhadap Penurunan Kadar Timah Hitam Dalam Darah (Studi Komunitas Siswa Sekolah Dasar di Kota Timah Bandung). Disertasi Program Doktor, Program Pascasarjana Fakultas Kesehatan Masyarakat, Universitas Indonesia; 2008. p. 90-1. https://doi.org/10.29408/ geodika.v4i1.1891

40. Ballew C, Bowman B. Recommending calcium to reduce lead toxicity in children: A critical review. Nutr Rev. 2001;59(3):71-9. https://doi.org/10.1111/j.1753-4887.2001.tb06991.x PMid:11330624

41. Angleton JP, Friedman DP, Mishkin M. A comparison between the connections of the amygdala and hippocampus with the basal forebrain in the macaque. Exp Brain Res. 1987;67(3):55668. https://doi.org/10.1007/bf00247288 PMid:2820778

42. Baier B, Karnath HO, Dieterich M, Birklein F, Heinze C, Müller NG. Keeping memory clear and stable the contribution of human basal ganglia and prefrontal cortex to working memory. J Neurosci. 2010;30(29):9788-92. https://doi.org/10.1523/ jneurosci.1513-10.2010 PMid:20660261

43. Cohen RL, Sandberg $\mathrm{T}$. The relation between intelligence and short-term memory. Cogn Psychol.1977;9(4):534-54. https:// doi.org/10.1016/0010-0285(77)90019-6

44. Salmaso D. Memory and aging: Components and processes. Funct Neurol. 1993;8(3):165-82

PMid:8406135 
45. Squire LR, Knowlton BJ. In: Memory WL, Saunders RC, editor. Memory, Hippocampus and Brain Systems. 1989. p. 825-37.

46. Heard MJ, Chamberlain AC. Effect of minerals and food on uptake of lead from the gastrointestinal tract in humans. Hum Toxicol. 1982;1(4):411-5. https://doi. org/10.1177/096032718200100407

PMid:7173926

47. Simon TJ. Cellular interactions between lead and calcium. $\mathrm{Br}$ Med Bull. 1986;42:431-4.

PMid:3308000

48. Han S, Pfizenmaier DH, Garcia E, Eguez ML, Ling $M$, Kemp FW, et al. Effects of lead exposure before pregnancy and dietary calcium during pregnancy on fetal development and lead accumulation. Environ Health Perspect. 2000;108(6):527-31. https://doi.org/10.1289/ehp.00108527 PMid: 10856026

49. Black KC, Barbezat GO, Mann M. Effect of dietary constituents on the gastrointestinal absorption of $203 \mathrm{~Pb}$ in Man. Environ Res. 1983;30:182-7.

50. Ziegler EE, Edward BB, Jensen RL, Mahaffey KR, Formon SJ. Absorption and relation of lead by infants. Pediatr Res. 1978;12(1):29-34.

PMid:643372

51. LedererLG,BingFC.Effectofcalciumand phosphorusonretention of lead by the Growing organism. JAMA. 1940;114(25):2457-61. https://doi.org/10.1001/jama.1940.62810250009009

52. Bogden JD, Gertner SB, Christakos S, Kemp FW, Yang Z, Katz SR, et al. Dietary calcium modifies concentrations of lead and other metals and renal calbindin in rats. J Nutr. 1992;122(7):1351-60. https://doi.org/10.1093/jn/122.7.1351 PMid:1619463

53. Quarterman J, Morrison JN, Humphries WR. The influence of high dietary calcium and phosphate on lead uptake and release. Environ Res. 1978;17(1):60-7. https://doi. org/10.1016/0013-9351(78)90061-0

54. Rosen JF, Chesney RW, Hamstra A, Mahaffey KR. Reduction in 1,25-dihydroxy vitamin $D$ in children with increased lead absorption. N Engl J Med. 1980;302(20):1128-31. https://doi. org/10.1056/nejm198005153022006

\section{PMid:7366636}

55. Shen XM, Guo D, Zhou J, Chonghuai Y. Intervening role of calcium on lead toxicity in children: experimental study and clinical verification. Chin J Child Health. 1993;1:157.

56. Li K, Wang XF, Li DY, Chen YC, Zhao LJ, Liu XG, et al. The good, the bad, and the ugly of calcium supplementation: $A$ review of calcium intake on human health. Clin Interv Aging. 2018;13:2443-52. https://doi.org/10.2147/cia.s157523 PMid:30568435

57. Granner DK. Hormon yang mengatur metabolisme kalsium. In: Murray RK, Granner DK, Rodwell VW, editor. Biokimia Harper. $25^{\text {th }}$ ed. Jakarta: EGC; 2003. p. 253.

58. Groleau V, Herold RA, Schall JI, Wagner JL, Dougherty KA, Zemel BS, et al. A. Blood lead concentration is not altered by high dose Vitamin $D$ supplementation in children and young adults with HIV. J Pediatr Gastroenterol Nutr. 2013;56(3):316-9. https://doi.org/10.1097/mpg.0b013e3182758c4a PMid:23059649

59. Gould E. Childhood lead poisoning: Conservative estimates of the social and economic benefits of lead hazard control. Environ Health Perspect. 2009;117(7):1162-7. https://doi.org/10.1289/ ehp.0800408 PMid:19654928

60. Pirkle JL, Brody DJ, Gunter EW, Kramer RA, Paschal DC, Flegal KM, et al. The decline in blood lead levels in the United States: The national health and nutrition examination surveys (NHANES). JAMA. 1994;272(4):284-91. https://doi.org/10.1001/ jama.1994.03520040046039

PMid:8028141 